\title{
Organizational Performance Influenced by Academic Service Quality: An Investigation in Public Universities in Malaysia
}

\author{
Sailesh Sharma $\mathbb{D D}^{1}$ and Saleh Al Sinawi ${ }^{2}$ \\ ${ }^{1}$ University of West Indies Open Campus, Kingston, Jamaica \\ ${ }^{2}$ A'Sharqiyah University, Ibra, Oman \\ Correspondence should be addressed to Sailesh Sharma; sharmuco@yahoo.com \\ Received 6 April 2019; Revised 12 September 2020; Accepted 4 January 2021; Published 19 January 2021 \\ Academic Editor: Ahmed Rachid \\ Copyright (c) 2021 Sailesh Sharma and Saleh Al Sinawi. This is an open access article distributed under the Creative Commons \\ Attribution License, which permits unrestricted use, distribution, and reproduction in any medium, provided the original work is \\ properly cited.

\begin{abstract}
The influence of service quality on organizational performance has captured a greater attention in corporate and academic world. The public universities in Malaysia are no different than such corporate world in terms of quality, services, and outcome. Hence, investigation of the influence of academic service quality on the organizational performance in public universities in Malaysia is the key attention of this study. A survey was conducted by drawing a sample of 435 international students from three public universities in Malaysia, by using a questionnaire developed by modification of SERVQUAL. The modified questionnaire assessing academic service quality comprises of five dimensions such as academic resources, academic competence, skills development, attitude, and responsiveness. Data obtained were analyzed by using techniques such as principal component analysis, one-way ANOVA, correlation, and multiple regression. Results indicated that the three universities provided the same level of academic service quality. It was also found that all the five dimensions of academic service quality significantly influenced the organizational performance. This study concludes by advocating the need of comparative studies between public and private universities in Malaysia and across countries.
\end{abstract}

\section{Introduction}

Undoubtedly, in the last decade, a successful era of transition and transformation is witnessed in public universities in Malaysia [1]. Such success is attributed to experiencing pressure from extreme competitions to securing, maintaining, and sustaining their position on top 100 QS ranking [1]. In accountability parade for reaching the milestone of QS ranking, Ministry of Higher Education (MOHE) introduced its Higher Education Blueprint 2015, which serves as a successful road map to ensure quality for learning and research outcomes. Quality Management and Enhancement Center (QMEC) in all Malaysian public universities has quality vision, mission, and objectives that contribute to manage, facilitate, and conduct activities towards quality assurance and enhancement of core processes based on the requirements of MS ISO 9001:2008 and the Malaysian Qualification Framework (MQF). Such quality systems contribute to desirable changes as argued by Costa and Lorente [2], in enhancing organization performance [3].

A considerable number of studies in the last two decades have laid emphasis on the conceptualization and measurement of service quality and its influence on a wide range of organizational outcomes $[2,4,5]$. Quality in services through effective practices of implementing quality management systems in public universities in Malaysia has shown exponential growth. Through such quality practices especially in services, the organizational performance of universities is ensured. Hence, a wide range of studies has focused on assessing the service quality using an influential tool SERVQUAL [3, 6-10]. However, SERVQUAL tool is criticized by a good number of scholars like Chua [6], Oldfield and Baron [11], and Sherry et al. [12], which is discussed in coming sections. Accepting SERVQUAL as such or modifying it with contextual needs is highly argued by many of abovementioned scholars, which creates a caveat in conceptualization of service quality in 
particular in the education sector. Hence, this study intends to fill the caveat by rigorous modification of SERVQUAL for assessing academic service quality and statistically ensuring its significance which we are going to discuss in coming sections. As discussed earlier that with service quality, organizational performance is ensured; therefore, it is important to study the academic service quality offered by these universities and its influence on organizational performance. Despite of the elusive nature of the conceptualization and perceptions of quality, there is an agreement on determination of quality parameters by the stake holders [13-16]. Universities in particular have a variety of stake holders such as academic faculty members, students, parents, nonacademic staff, industry, and community, of whom, the students are the most important stakeholders and their views cannot be ignored $[3,5,17]$. In the context of public universities in Malaysia, international students are also one of the most important stake holders, and hence, their expectations and satisfaction are taken on high priority by the university management [18]. The rationale behind considering international students as one of the important stake holders is that the tuition fees they contribute is the major income for universities and other higher educational institutions. Hence, the importance of financial contribution by international students to the national income (Ministry of Higher Education (MOHE), 2012) set up a strategic plan known as Strategic Plan of Malaysian Higher Education in view to achieve the goals, vision, and mission for Malaysia to become a hub of educational excellence of higher education by the year 2020. In view to expedite accomplishment of such optimistic vision, the Malaysian universities stepped up to increase enrollment of international students and made it imperative to know the perception of these international students about qualities and services provided by the universities. Importance of perceptions of international students is highly advocated by a good number of scholars like [19] in different context and [18] in Malaysian context. Though it is important to consider the perceptions of other stake holders such as academic faculty members, students, parents, nonacademic staff, industry, and community which this study has carried out, however, this article intends to focus on international students owing to the above stated reasons. Also following the Malaysia determination to attract more international students to come and study in Malaysian HEIs, therefore, this study of international students is wisely to be conducted. As stated earlier, Malaysian universities ensure quality in academics through their services, and we intend to focus on academic service quality in this study. Studying academic service quality in isolation provides incomplete image of quality in institutions of higher learning; hence, in what context such academic quality should be studied? A wide range of studies are found to be carried on quality in terms of student satisfaction [20,21], and such type of studies is treated as a trivial way on approaching the issue of service quality [22, 23]. However, there are two ways of studying such quality issues leadership and performances. Leadership of institutions needs to spearhead quality in terms to demonstrate the high level of performance [1]. However, leadership to spearhead quality is beyond the scope of this article; hence, only service quality and organizational performance is to be studied in this article.
This study, therefore, intends to investigate the academic service quality and organizational effectiveness in three public universities in Malaysia. In particular, the study intends to explore the dimensions of academic service quality that influence organizational performance in the three selected universities and examine the differences if any in service quality and organizational performance among the three universities. This study intends to answer the following questions.

(1) What are the perceptions of international students on academic service quality provided and subsequent organizational performance in three public universities?

(2) Do the perceptions of international students on academic service quality and subsequent organizational performance differ significantly in three universities?

(3) Is there any significant relationship between various factors of academic service quality and organizational performance in three Malaysian universities?

(4) Which factors of academic service quality are significant predictors of organizational performance in three Malaysian universities?

\subsection{Literature Review}

1.1.1. Conceptualizing Service Quality. In the past two decades, researchers have shown their interest on service quality which has provoked discussions on the theme of elusiveness in terms of definition and measurement $[3,10,24]$. In spite of their arguments, there is a common belief and understanding among researchers that service quality is to meeting customers' expectations in order to enhance organizational performance [3, 10, 25]. Growing interest on measuring service quality, though a wide range of instruments was used, SERVQUAL captured the utmost interest of researchers [3, 9, 10, 26, 27]. The dominance of SERVQUAL over other instruments was even acknowledged by the critics $[3,9,10,28]$. The 22 items of SERVQUAL categorized into the five dimensions-assurance, empathy, reliability, responsiveness, and tangibles-have provoked industries, academicians, corporates, and practitioners [3, 6-10]. Along with it, with modifications in the contents and number of items in five dimensions, SERVQUAL has been used extensively to measure service quality in a broad range of organizations $[3,29]$, in universities, and other higher educational institutes $[3,9,10]$. This is in accordance with assertion by Parasuraman et al. [26] that, with modification in constructs, SERVQUAL supports for service quality research studies in measuring service quality in different contexts.

1.1.2. Service Quality in Higher Education. As discussed earlier, a common agreement on quality definition and perception of quality confirms that quality needs to be determined by the stakeholders $[3,7,10,25]$ and customer 
focus is undebatable necessity [30]. Webb et al. [31] argues that "it is logical and intuitive that beneficial strategic insights can be gained when the firms take into account their customer's view on the organizational level of service quality." In particular, a wide range of customers such as parents, academic faculties, students, industries, linkages, and community are served by universities and views on quality cannot be ignored, as it brings forward a big argument that whose views are prime. As mentioned earlier, the 22 items of SERVQUAL categorized into five dimensions-assurance, empathy, reliability, responsiveness, and tangibles-have provoked industries, academicians, corporates, and practitioners $[3,6-10]$. In spite of such huge admiration of SERVQUAL, this instrument has faced a lot of criticism in research studies focusing higher educational service quality. First, this instrument SERVQUAL measures the gap between services expected and services received. However, this notion of studying gaps is highly criticized by Chua [32], Oldfield and Baron [11], and Sherry et al. [12], as these researchers found that the gap scores obtained could not provide a true picture. These scholars further argue that some of the dimensions only cater to the need of other service sectors not education and recommended to use SERVQUAL in isolation as service received. However, in this study, we have considered international students as one of the important customers and paid attention to their perspective on service quality. As mentioned earlier, keeping in view the prime focus of this study perception of international students and perspectives on quality in Malaysian context, we have focused two different notions of service quality measurements:

(1) Conceptualization of service quality by Owlia and Aspinall [33] which emphasizes on academic resources, content, attitude, and competence

(2) Waugh [34] frameworks with emphasis on empathy, reliability, assurance, and responsiveness

Since this study is focused on perception of international students' in Malaysian context, some of the dimensions from SERVQUAL, Owlia and Aspinall [33] and Waugh [34], are either replaced or discarded. For example, tangibles are replaced by academic resources as per recommendation of Owlia and Aspinall [33]; competence is modified to academic competence and content to skills development as described by Malaysian Education Framework. The subscales of the instrument for measurement of higher education academic service quality are described in Table 1.

\subsubsection{Conceptualizing Organizational Performance.} Organizational performance in Malaysian context is highly debated in terms of satisfaction of stakeholders [35]. Scholars like Majid [36] and Yunus [37] have asserted that for sustainability of any institute of higher education in Malaysia, organizational performance is vital. These scholars further emphasized on various factors that determine organizational performance in Malaysian higher education context related to satisfaction of customers with services, facilities, image, quality of products, and market value of graduates through employability. These factors are in total agreement with the factor stated by Thomas and Maru [3] who studied the performance in terms of facilities, programs, services, image quality of graduates, responsiveness to student concern, and graduation rates of students; hence, in this study, the organizational performance is examined in relation to academic service quality as discussed above.

\section{Methodology}

In this study, the influence of academic service quality on organizational performance in public universities in Malaysia is explored through a survey. Such exploratory research design is appropriate in investigating and understanding the context of service quality and organizational performance, Thomas and Maru [3]. The survey was carried out in three public universities in Malaysia with approximate population of 8000 international students. From such population, a sample of 435 students was selected. This sample size was sufficient as the minimum required sample for such population is 367 [38]. First, the systematic sampling method was utilized to select five faculties from each university. Then, 29 respondents were randomly selected from these faculties, thus making 145 respondents from each university to ensure equality. The respondents were provided with a specifically designed questionnaire. Before administration of the questionnaire for the actual study, the questionnaire was pretested through a pilot study in a public university in Malaysia which was not a part of this study. Cronbach alpha was used to test internal consistency.

2.1. Data Collecting Tool. A questionnaire on academic service quality drawn upon a wide range of literature and from three different framework and models such as SERVQUAL $[39,40]$ and the service quality model by Owlia and Aspinall [33] and Waugh [34] was designed to collect data. This questionnaire on academic service quality included five dimensions, which are, attitude, academic competence, academic resources, skills development, and responsiveness.

Attitude anchored on abilities of academic staff in understanding and meeting academic needs of students. Academic competence anchored on a wide range of competencies such as pedagogical skills, communication skills, and theoretical and practical knowledge of faculty members that directly influence learning. Academic resources anchored on a wide range of facilities provided that are essential for academic development of students. Some examples are physical and digital library, laboratories, instructional materials, and journals. Skills development anchored on various skills such as communication skills, leadership skills, life-long learning skills, and ethical and moral skills that are the key domains of Malaysian Qualification Framework. Responsiveness anchored on readiness and willingness of faculty members in helping students and exhibiting courteous and polite behaviour towards students. While, nine items were adopted from Thomas and Maru [3] to rate organizational performance. These items included 
facilities, programs, services, image quality of graduates, responsiveness to student concern, and graduation rates of students. All of the items of service quality and organizational performance were measured through five-point rating scales $1-5$, where 1 represented strongly disagree and 5 represented strongly agree.

2.2. Data Analysis Procedure. Data obtained through administration of the questionnaire was subjected to various statistical techniques such as Cronbach's alpha to test internal consistency [41], principal component analysis with varimax rotation to extract factor loadings with subsequent extraction of dimensions [41], descriptive and inferential through ANOVA to explain the difference of means among perception of students in three public universities, correlation and multiple regression analysis to determine the relationship existing between two variables, and influence of academic service quality on organizational performance [42]. Prior to using analytical methods, normality, validity, and reliability of constructs were measured. Variance inflation factor (VIF) was also calculated to test the absence of multicollinearity using the recommended threshold of VIF values less than 10 [41]. The VIF values were all acceptable at score 2.0 .

\section{Results and Discussion}

This section presents reliability statistics, principal component analysis descriptive statistics in terms of means and standard deviations, one-way ANOVA, correlation, and multiple regression analysis results calculated from data obtained by administration of the questionnaire designed to study perception of international students on academic service quality and organizational performance in three public universities. As discussed earlier, the questionnaire was distributed to 435 international students, and all of the 435 respondents administered the questionnaire; the rate of response rate was $100 \%$ from three selected public universities in Malaysia.

3.1. Reliability Statistics. Interitem analysis is used to confirm the scales of service quality dimensions and organizational performance for reliability. In particular, Cronbach's $\alpha$ is calculated for each scale as suggested by Hair et al. [41]. Internal consistency for 5 items of skills development is found consistent with Cronbach $\alpha=0.903$, responsiveness ( 3 items) with Cronbach $\alpha=0.892$, academic competence with Cronbach $\alpha=0.841$, attitude ( 4 items) with Cronbach $\alpha=0.838$, academic resource (4 items) with Cronbach $\alpha=0.836$, and organizational performance (9 items) with Cronbach $\alpha=0.899$. All internal consistency scores are $>0.7$ which is acceptable threshold [41].

3.2. Factor Analysis. As evident from Table 2, five factors of service quality were extracted through principal component analysis which accounted for $86.4 \%$ of total variation. A cutoff of 0.50 was used for item scale selection, and varimax rotation was used to identify interpretable structure. Five principal components were obtained corresponding to 5 service quality measures from factor loadings of items. Besides, the degree of the correlation between the variables through Bartlett sphericity $(p<0.001)$ and appropriateness of the sample according to Kaiser-Meyer-Olkin index $(\mathrm{KMO}<0.85)$ was also verified. Similarly, the organizational performance was subjected to factor analysis of the item, and the results are accepted following the Kaiser-Meyer-Olkin index of 0.81 and significant Bartlett sphericity [41]. The results verified the construct validity of the instrument used and signified the appropriateness of the factors for each construct in the context of Malaysian public universities. The results are in accordance with the findings by various scholars $[29,43]$ who claim that the five dimensions of SERVQUAL with modifications in contents and number of items can be used to measure service quality across various organizations and in institutes of higher learning $[3,9,10]$. These results also support the claim by Parasuraman et al. [26] that SERVQUAL with adjustments and content modifications can be used for specific needs.

3.3. Descriptive Statistics and ANOVA. Student perception on five dimensions of service quality and organizational performance was drawn out through administration of a questionnaire. From Table 3, it is evident that student perception on service quality and organizational performance is highly positive. Students from these three universities recognize academic resources to be the most dominant service quality dimension. This is attributed to the initiatives taken by Ministry of Higher Education in Malaysia in providing a high quality infrastructure and adequate resources such as laboratories, workshops, resource centers, and easy access to various online libraries and journals. These resources are crucial for intellectual development of students and create the conducive learning environment for students [3, 44].

The second important dimension recognized from the perception of students is academic competence. The theoretical and pedagogical knowledge of teaching staff, expertise in teaching and research, and communication skills are the crucial quality elements prerequisite for academic staff as documented in Malaysian Qualification Framework. This attributes to the top management of universities in recruiting competent academic staff and probity of academic staff towards teaching and the learning process and equips academic staff with pedagogical knowledge and skills. Importance of pedagogical knowledge and skills is highly advocated by scholars like Robinson and Hope [45] and Kamel [46]. These scholars argue that pedagogical knowledge and skills of faculty members improves academic competence of them in lieu, and they show their confidence in teaching and research by communicating with students with high confidence. The findings of this study are in high agreement with Robinson and Hope [45] and Kamel [46], as faculty members in these three universities are rated highly by the students.

Following academic competence, skills development is recognized as the third important dimension perceived by 
TABLE 1: The survey instrument for academic quality services.

\begin{tabular}{lcc}
\hline $\begin{array}{l}\text { Quality dimension } \\
\text { Academic resources }\end{array}$ & Adequacy of resources, e.g., physical library, resource center, laboratory, and digital library & No. of items \\
\hline $\begin{array}{l}\text { Academic } \\
\text { competence }\end{array}$ & $\begin{array}{c}\text { Academic and pedagogical knowledge of teaching staff, expertise in teaching and scholarship, and } \\
\text { communication skills of teaching staff }\end{array}$ & 4 \\
\hline $\begin{array}{l}\text { Skills development } \\
\text { Attitude }\end{array}$ & $\begin{array}{c}\text { Degree to which various programs develop communication, leadership, team work, life-long learning } \\
\text { skills, and moral and ethical skills }\end{array}$ \\
\hline $\begin{array}{c}\text { Extent to which the faculty members understand and fulfil students' academic needs, guide, and } \\
\text { advise students }\end{array}$ & 4 \\
\hline
\end{tabular}

students in these three Malaysian universities. It reflects that academic staffs in these universities have competencies in developing skills such as communication, leadership, lifelong learning, teamwork, and moral and ethical crucial to Malaysian Qualification Framework. These skills are considered as most significant contributors of employability and long-term sustainability of graduates [47, 48]. The findings of this study suggest that with the ability to develop a wide range of skills, the academic staff of these three Malaysian universities significantly develop competencies of employability and sustainability of their graduates, and these findings are in agreement with $[47,48]$.

Attitude and responsiveness are the last two dimensions recognized from the perception of students. These two dimensions corresponding to the extent of realizing students' academic needs, guiding students, and readiness in helping and responding to students are highly subjective. Malaysian public universities cater to the needs of students from various continents, nations, races, and ethnic groups through academic staff from diversified background. Such diversification accounts for diversified needs and ways of meeting it. Even though these two dimensions have the least ratings compared to the earlier three, the complexity of realizing academic needs or helping and responding to students in diversified environment needs more exploratory outlook and depends on individual academic staff's abilities and university top management initiatives in developing these abilities in academic staff.

It is also found that perception of international students regarding organizational performance of their university is highly positive in all three universities in Malaysia. This reveals the satisfaction of international students with performance of their university. It clearly signifies that satisfaction of customers with services, facilities, image, quality of products, and market value of graduates through employability in these universities is in agreement with Beh [35], Majid [36], Thomas and Maru [3], and Yunus [37].

Findings from one-way ANOVA indicates that the perception of students for five dimensions of academic service quality and single construct of organizational performance do not differ significantly across the three public universities in Malaysia. These findings are in agreement with Thomas and Maru [3], where it was found that the service quality and performance in three African universities do not differ significantly on the basis of student's perception. These results clearly signify that these three universities are successful in providing academic service quality and performance as expected by Ministry of Higher Education in Malaysia.

\subsection{Correlation between Service Quality and Organizational} Performance. The relationship between the five dimensions of academic service quality and organizational performance was explored through Pearson's product moment correlation. The correlation that established the relationship between service quality and organizational performance is shown in Table 4.

In Table 4, the correlation analysis shows that all the five dimensions of academic service quality are significantly correlated with organizational performance. The correlation coefficient of organizational performance with academic resources was $r=0.72 ; p<0.01$, academic competence $(r=0.68 ; p<0.01)$, skills development $(r=0.65 ; p<0.01)$, responsiveness $(r=0.62 ; p<0.01)$, and attitude $(r=0.59$; $p<0.01)$. Intervariable correlation ranges between $r=0.57$ and $r=0.72$. These results are consistent with the earlier studies which confirm that improvement in quality increases the organizational performance $[3,49]$.

3.5. Regression Analysis. Influence of academic service quality on organizational performance was verified using regression analysis. It is found that the academic service quality accounts for $58.4 \%$ of variance in organizational performance as given in Table 5. Evidences from regression coefficients reveal that all five dimensions of service quality significantly and positively influence organizational performance. In terms of the relationship between predictor variables and dependent variables, the standardized betas reveal that academic resources $(\beta=0.356)$, academic competence $(\beta=0.314)$, skills development $(\beta=0.295)$, attitude $(\beta=0.284)$, and responsiveness $(\beta=0.281)$ significantly and positively influence organizational performance. Further examination indicates that academic resources and academic competence have the largest effect on organizational performance followed by skills development, attitude, and responsiveness as given in Table 5. This confirms the dominance of academic resources and academic competence to organizational performance and can be argued that by providing adequate academic resources and competent academic staff, universities in Malaysia have stepped ahead to achieve the targets set by Higher Education Blueprint 2015 
TABLE 2: Principal component analysis for academic service quality.

\begin{tabular}{|c|c|c|c|c|c|}
\hline & Academic resources & Academic competence & Skills development & Attitude & Responsiveness \\
\hline Item 1 & 0.837 & $\mathrm{x}$ & $\mathrm{x}$ & $\mathrm{x}$ & $\mathrm{x}$ \\
\hline Item 2 & 0.818 & $\mathrm{x}$ & $\mathrm{x}$ & $\mathrm{x}$ & $\mathrm{x}$ \\
\hline Item 3 & 0.848 & $\mathrm{x}$ & $\mathrm{x}$ & $\mathrm{x}$ & $\mathrm{x}$ \\
\hline Item 4 & 0.864 & $\mathrm{x}$ & $\mathrm{x}$ & $\mathrm{x}$ & $\mathrm{x}$ \\
\hline Item 5 & $\mathrm{x}$ & 0.779 & $\mathrm{x}$ & $\mathrm{x}$ & $\mathrm{x}$ \\
\hline Item 6 & $\mathrm{x}$ & 0.801 & $\mathrm{x}$ & $\mathrm{x}$ & $\mathrm{x}$ \\
\hline Item 7 & $\mathrm{x}$ & 0.786 & $\mathrm{x}$ & $\mathrm{x}$ & $\mathrm{x}$ \\
\hline Item 8 & $\mathrm{x}$ & 0.712 & $\mathrm{x}$ & $\mathrm{x}$ & $\mathrm{x}$ \\
\hline Item 9 & $\mathrm{x}$ & $\mathrm{x}$ & 0.833 & $\mathrm{x}$ & $\mathrm{x}$ \\
\hline Item 10 & $\mathrm{x}$ & $\mathrm{x}$ & 0.827 & $\mathrm{x}$ & $\mathrm{x}$ \\
\hline Item 11 & $\mathrm{x}$ & $\mathrm{x}$ & 0.814 & $\mathrm{x}$ & $\mathrm{x}$ \\
\hline Item 12 & $\mathrm{x}$ & $\mathrm{x}$ & 0.788 & $\mathrm{x}$ & $\mathrm{x}$ \\
\hline Item 13 & $\mathrm{x}$ & $\mathrm{x}$ & 0.746 & $\mathrm{x}$ & $\mathrm{x}$ \\
\hline Item 14 & $\mathrm{x}$ & $\mathrm{x}$ & $\mathrm{x}$ & 0.811 & $\mathrm{x}$ \\
\hline Item 15 & $\mathrm{x}$ & $\mathrm{x}$ & $\mathrm{x}$ & 0.736 & $\mathrm{x}$ \\
\hline Item 16 & $\mathrm{x}$ & $\mathrm{x}$ & $\mathrm{x}$ & 0.685 & $\mathrm{x}$ \\
\hline Item 17 & $\mathrm{x}$ & $\mathrm{x}$ & $\mathrm{x}$ & 0.762 & $\mathrm{x}$ \\
\hline Item 18 & $\mathrm{x}$ & $\mathrm{x}$ & $\mathrm{x}$ & $\mathrm{x}$ & 0.581 \\
\hline Item 19 & $\mathrm{x}$ & $\mathrm{x}$ & $\mathrm{x}$ & $\mathrm{x}$ & 0.637 \\
\hline Item 20 & $\mathrm{x}$ & $\mathrm{x}$ & $\mathrm{x}$ & $\mathrm{x}$ & 0.791 \\
\hline Eigen values & 3.74 & 3.41 & 3.13 & 2.87 & 2.65 \\
\hline Percentage of total variation & 22.7 & 20.5 & 17.6 & 14.8 & 10.8 \\
\hline Cumulative percentage of variation & 22.7 & 43.2 & 60.8 & 75.6 & 86.4 \\
\hline
\end{tabular}

Notes: varimax with Kaiser normalization; all loadings less than 0.5 are compressed.

TABle 3: Descriptive statistics and ANOVA results for academic service quality and organizational performance.

\begin{tabular}{|c|c|c|c|c|c|c|}
\hline & & University 1 & University 2 & University 3 & $F$ value & $p$ value \\
\hline \multirow{2}{*}{ Academic resources } & Mean & 4.43 & 4.41 & 4.49 & \multirow{2}{*}{1.36} & \multirow{2}{*}{0.12} \\
\hline & SD & 0.67 & 0.64 & 0.71 & & \\
\hline \multirow{2}{*}{ Academic competence } & Mean & 4.42 & 4.36 & 4.38 & \multirow{2}{*}{1.12} & \multirow{2}{*}{0.32} \\
\hline & $\mathrm{SD}$ & 0.65 & 0.74 & 0.77 & & \\
\hline \multirow{2}{*}{ Skills development } & Mean & 4.35 & 4.29 & 4.31 & \multirow{2}{*}{1.09} & \multirow{2}{*}{0.71} \\
\hline & SD & 0.74 & 0.69 & 0.74 & & \\
\hline \multirow{2}{*}{ Attitude } & Mean & 4.24 & 4.19 & 4.21 & \multirow{2}{*}{1.47} & \multirow{2}{*}{0.27} \\
\hline & $\mathrm{SD}$ & 0.69 & 0.63 & 0.68 & & \\
\hline \multirow{2}{*}{ Responsiveness } & Mean & 4.14 & 4.05 & 4.09 & \multirow{2}{*}{1.27} & \multirow{2}{*}{0.36} \\
\hline & SD & 0.62 & 0.67 & 0.60 & & \\
\hline \multirow{2}{*}{ Organizational performance } & Mean & 4.26 & 4.18 & 4.23 & \multirow{2}{*}{1.52} & \multirow{2}{*}{0.49} \\
\hline & SD & 0.68 & 0.62 & 0.641 & & \\
\hline
\end{tabular}

TABLE 4: Correlation between academic service quality dimensions and organizational performance.

\begin{tabular}{cccccc}
\hline & Academic resources & Academic competence & Skills development & Attitude & Responsiveness \\
\hline Organizational performance & $0.72^{* *}$ & $0.68^{* *}$ & $0.65^{* *}$ & $0.59^{* *}$ & $0.62^{* *}$ \\
\hline
\end{tabular}

${ }^{* *} p<0.001$.

towards top 100 QS ranking. As asserted by scholars like Hope and Robinson [45] and Kamel [46], academic resources and academic competence are two important factors which students expect from their learning organization, and hence, it can be advocated from these findings that both these factors are contributing significantly for enrollment of students in Malaysian universities. It is also envisaged that skills development, attitude, and responsiveness also significantly contribute to organizational performance. In particular, the importance of skills development in employability and sustainability of a graduate was advocated by $[47,48]$; Malaysian universities are now preferred by international students in pursuing their higher education.

As mentioned earlier, this study has utilized three different frameworks to describe academic service quality and most of its dimensions are modified and renamed as per the local Malaysian universities context, and it can be argued that local context provides a better understanding for 
TABLE 5: Regression analysis for effects of service quality on organizational performance.

\begin{tabular}{|c|c|c|c|c|c|}
\hline \multirow{2}{*}{ Model } & \multicolumn{3}{|c|}{ Standardized coefficients } & \multicolumn{2}{|c|}{ Collinearity diagnosis } \\
\hline & $\beta$ & $t$ & $p$ & Tolerance & VIF \\
\hline Academic resources & 0.356 & 6.251 & 0.00 & 0.521 & 1.623 \\
\hline Academic competence & 0.314 & 6.154 & 0.00 & 0.507 & 1.746 \\
\hline Skills development & 0.295 & 6.542 & 0.00 & 0.538 & 1.826 \\
\hline Attitude & 0.284 & 6.338 & 0.00 & 0.522 & 1.541 \\
\hline Responsiveness & 0.281 & 6.470 & 0.00 & 0.514 & 1.712 \\
\hline
\end{tabular}

Notes: $R^{2}=0.589$; adjusted $R^{2}=0.584 ; F=87.68 ; p=0.000$. Dependent variable, organizational performance.

academic service quality, rather than using SERVQUAL as in its original form. This is further evidenced by the dimensions such as skills development, attitude, and responsiveness which are significant predictors of organizational performance as these dimensions too are derived from the context of Malaysian universities. In fact, in all Malaysian universities, lecturers are evaluated by the students for each course taught to them, and most of the content areas besides resources and competencies are reflected by skills development, attitude, and responsiveness. This can be further argued that academic staffs in Malaysian universities are not only competent in providing skills development but also in spite of facing various challenges as discussed earlier, they leave no stone unturned in helping students, meeting their needs and providing a responsive system for students. Such academic service quality provided by Malaysian universities is transforming Malaysia into global educational hub in Asia.

\section{Conclusions}

The present study proves that the adjusted and modified dimensions of SERVQUAL have successfully captured academic service quality in public universities in Malaysia. The perception of international students on academic service quality and organizational performance is found to be positive. Dominance of academic resources and academic competence is established while importance of skills development, attitude, and responsiveness are also confirmed in three Malaysian universities. Such results indicate that academic faculty members in public universities in Malaysia are highly competent in delivering academic service quality, which attracts international students pursuing studies in Malaysian universities. Academic faculty members in these universities not only care for academic well-being of students but also are deeply involved in developing skills in students. With their positive attitude and responsiveness towards issues related to students, they have created a sound flawless academic quality system. Organizational performance as expressed in terms of facilities, programs, services, image quality of graduates, responsiveness to student concern, and graduation rates of students highly rated by students clearly indicates the satisfaction of international students with service quality provided by the university. However, no significant differences in academic service quality and organizational performance among the three universities are observed.

\section{Implications}

The findings imply the concurrence in policies, quality issues, and initiatives taken by Ministry of Higher Education in Malaysia towards their Education Blueprint 2015. This further adds to wisdom of academic faculty members in these universities in dealing with initiatives of Ministry of Higher Education in fulfilling their vision through implementing best parameters of academic service quality. Furthermore, all the dimensions of academic service quality show a significant influence on organizational performance and confirmed the relative importance of each dimension of academic service quality on organizational performance in universities in Malaysia.

This study confirms the adoption of principles of academic service quality as a necessary condition for organizational performance particularly in universities in Malaysia; however, such principles should address the local and organizational issues. As evident, all the dimensions of service quality are modified as per Malaysian universities context taking into consideration ISO and Malaysian Qualification Requirements; this study has further confirmed the importance of quality in higher education as a social and political issue with implications on local context [49].

\section{Suggestions for Further Research}

Since public universities are caught up with variety of issues such as globalization, accountability, competition, and global ranking, implications of this study demand further research studies on comparing private and public universities in Malaysia and interuniversity comparisons across countries. It is also suggested to have a comparative study among students (local and international) in these universities. This study has utilized quantitative approach to address its findings; it is suggested that exploratory and mixed method approaches will lead to more understanding on the issue. The findings of this study will enable policy makers and administrators to explicitly look upon the areas of concerns and improve upon. It is also suggested that policy makers, administrators, and stake holders in Malaysia should work in collaboration to develop the comprehensive and contextual perspectives of academic service quality and organizational performance which can contribute to mobilizing its universities in higher ranking. 


\section{Data Availability}

The raw data obtained as a result of administration of instruments used are a part of a large scale study and will be used for further research by authors themselves. Hence, the raw data cannot be shared. The analyzed data can be shared after publication of this manuscript and are available from the corresponding author upon request.

\section{Conflicts of Interest}

The authors declare that they have no conflicts of interest.

\section{References}

[1] S. Sharma, S. D. Amir, S. Veeriah, and S. Kannan, "Leadership of deans and its impact on effectiveness for quality in a high ranking university," Education \&Science, vol. 41, no. 184, pp. 49-58, 2016.

[2] M. M. Costa and M. A. R. Lorente, "A triple analysis of ISO 9000 effects on company performance," International Journal of Productivity and Performance Management, vol. 55, no. 5, pp. 484-499, 2007.

[3] K. C. Thomas and L. C. Maru, "Service quality and relative performance of public universities in East Africa," The TQM Journal, vol. 25, no. 5, pp. 533-546, 2013.

[4] G. P. M. Dick, "ISO 9000 certification benefits, reality or myth?” The TQM Magazine, vol. 12, no. 6, pp. 365-371, 2000.

[5] M. Kashif, T. Ramayah, and S. Sarifuddin, "PAKSERV-measuring higher education service, quality in a collectivist cultural context," Total Quality Management \& Business Excellence, vol. 27, 2014.

[6] K.-K. Chen, C.-T. Chang, and C.-S. Lai, "Service quality gaps of business customers in the shipping industry," Transportation Research Part E: Logistics and Transportation Review, vol. 45, no. 1, pp. 222-237, 2009.

[7] T. Lazibat, T. Bakovic, and I. Duzevic, "How perceived service quality influences students', satisfaction? teachers' and students' perspectives," Total Quality Management \& Business Excellence, vol. 25, no. 8, pp. 923-934, 2014.

[8] F. Pakdil and Ö. Aydın, "Expectations and perceptions in airline services: An analysis using weighted SERVQUAL scores," Journal of Air Transport Management, vol. 13, no. 4, pp. 229-237, 2007.

[9] P. Trivellas and D. Dargenidou, "Leadership and service quality in higher education," International Journal of Quality and Service Sciences, vol. 1, no. 3, pp. 294-310, 2009 b.

[10] S. Zainuddin, M. H. Kahmis, A. Muhamad, and N. Mammat, "Perception and expectations of students towards the service quality: perspective in Malaysian research university," Malaysian Online Journal of Educational Management, vol. 2, no. 2, pp. 73-91, 2015.

[11] B. M. Oldfield and S. Baron, "Student perceptions of service quality in a UK university business and management faculty," Quality Assurance in Education, vol. 8, no. 2, pp. 85-95, 2000.

[12] C. Sherry, R. Bhat, B. Beaver, and A. Ling, "Students as customers: the expectations and perceptions of local and international students," in Proceedings of the HERDSA 2004 Conference, Sarawak, Malaysia, July 2004.

[13] G. K. Kanji and A. Malek, "Total Quality Management in UK higher education institutions," Total Quality Management, vol. 10, no. 1, pp. 129-153, 1999.
[14] A. Tambi, "Quality and management in universities," Journal of Tertiary Education Administration, vol. 16, no. 1, pp. 55-68, 1994.

[15] H. Nadiri, J. Kandampully, and K. Hussain, "Students' perceptions of service quality in higher education," Total Quality Management \& Business Excellence, vol. 20, no. 5, pp. 523$535,2009$.

[16] M. Tam, "Quality assurance policies in higher education in Hong Kong," Journal of Higher Education Policy and Management, vol. 21, no. 2, pp. 215-226, 1999.

[17] P. Sander, K. Stevenson, M. King, and D. Coates, "university students' expectations of teaching," Studies in Higher Education, vol. 25, no. 3, pp. 309-323, 2000.

[18] S. F. Padlee and A. Y. Yaakop, "Service quality of Malaysian higher educational institutions: a conceptual framework," International Journal of Business, Economics and Law, vol. 2, no. 1, pp. 60-69, 2013.

[19] C. Munteanu, C. Ceobanu, C. Bobâlcă, and O. Anton, "An analysis of customer satisfaction in a higher education context," International Journal of Public Sector Management, vol. 23, no. 2, pp. 124-140, 2010.

[20] R. Arambewela and J. Hall, "An empirical model of international student satisfaction," Asia Pacific Journal of Marketing and Logistics, vol. 21, no. 4, pp. 555-569, 2009.

[21] T. Gruber, S. Fuß, R. Voss, and M. Gläser-Zikuda, "Examining student satisfaction with higher education services," International Journal of Public Sector Management, vol. 23, no. 2, pp. 105-123, 2010.

[22] O. W. DeShields Jr, A. Kara, and E. Kaynak, "Determinants of business student satisfaction and retention in higher education: applying Herzberg's two-factor theory," International Journal of Educational Management, vol. 19, no. 2, pp. 128139, 2005.

[23] M. M. Navarro, M. P. Iglesias, and P. R. Torres, "A new management element for universities: satisfaction with the offered courses," International Journal of Educational Management, vol. 19, no. 6, pp. 505-526, 2005.

[24] M. Wisniewski, "Using SERVQUAL to assess customer satisfaction with public sector services," Managing Service Quality: An International Journal, vol. 11, no. 6, pp. 380-388, 2001.

[25] B. R. Lewis and V. W. Mitchell, "Service quality gaps of business customers in the shipping industry, transportation research part E," Logistic and Transportation Review, vol. 41, no. 1, pp. 222-237, 2009.

[26] A. Parasuraman, V. A. Zeithaml, and L. L. Berry, "Reassessment of Expectations as a Comparison Standard in Measuring Service Quality: Implications for Further Research," Journal of Marketing, vol. 58, no. 1, pp. 111-124, 1994.

[27] S. Sahney, D. K. Banwet, and S. Karunes, "Conceptualizing total quality management in higher education," The TQM Magazine, vol. 16, no. 2, pp. 145-159, 2004.

[28] P. Asubonteng, K. J. McClearly, and J. E. Swan, "SERVQUAL revisited: a critical review of service quality," The Journal of Service Marketing, vol. 10, no. 2, pp. 62-81, 1996.

[29] A. Akaba, "Measuring service quality in the hotel industry: a study in business hotels in Turkey," Hospitality Management, vol. 25, no. 2, pp. 170-192, 2006.

[30] R. A. Heiens, "Market orientation toward an integrated framework," Academy of Marketing Science Review, no. 1, pp. 1-4, 2000.

[31] D. Webb, C. Webster, and A. Krepapa, "An exploration of the meaning and outcomes of a customer-defined market 
orientation," Journal of Business Research, vol. 48, no. 2, pp. 101-112, 2000.

[32] C. Chua, "Perception of quality in higher education," in Proceedings of the Australian Universities Quality Forum, AUQA Occasional Publication, Adelaide, Australia, July 2004.

[33] M. S. Owlia and E. M. Aspinwall, "TQM in higher education a review," International Journal of Quality \& Reliability Management, vol. 14, no. 5, pp. 527-543, 1997.

[34] R. F. Waugh, "Academic staff perception of administrative quality at universities," Journal of Educational Administration, vol. 2, no. 2, pp. 172-188, 2001.

[35] L. S. Beh, "Public sector performance in Malaysia: an evaluation of employee empowerment and self-leadership," Research Journal of Economics, Business and ICT, vol. 9, no. 1, pp. 8-12, 2014.

[36] M. Majid, Relationship of human capital, service delivery and organizational performance, Examining the Moderating Effect of Organizational Culture in Malaysian Government Ministries, University Teknologi MARA, PhD. thesis, 2017.

[37] A. J. Yunus, Human Capital Development and Performance Management, Programme for Local Government and District Management, National Institute of Public Administration, Kuala Lumpur, Malaysia, 2008.

[38] R. V. Krejcie and D. W. Morgan, "Determining sample size for research activities," Educational and Psychological Measurement, vol. 30, no. 3, pp. 607-610, 1970.

[39] A. Parasuraman, V. A. Zeithaml, and L. L. Berry, "Alternative scales of measuring service quality: a comparative assessment based on psychometrics tests and diagnostic criteria," Journal of Retailing, vol. 70, no. 3, pp. 201-230, 1985b.

[40] V. A. Zeithaml, A. Parasuraman, and L. L. Berry, Quality Service: Balancing Customer Perceptions and Expectations, Free Press, New York, NY, 1990.

[41] J. F. Hair, W. C. Black, B. J. Babin, R. E. Anderson, and R. L. Tatham, Multivariate Data Analysis, Pearson Education International, Upper Saddle River, NJ, USA, 7th edition, 2010.

[42] Y. P. Chua, Mastering Research Statistics, McGraw-Hill Education, New York, NY, USA, 2013.

[43] D. W. Finn and C. W. Lamb Jr., "An evaluation of SERVQUAL scales in a retailing setting," Advances in Consumer Research, vol. 18, no. 1, pp. 483-490, 1991.

[44] M. Ndirangu and M. O. Udoto, "Challenges for teaching and learning in Kenya's public universities," Quality Assurance in Education, vol. 19, no. 3, pp. 208-223, 2011.

[45] T. E. Robinson and W. C. Hope, "Teaching in higher education: is there a need for training in pedagogy in graduate degree program," Research in Higher Education Journal, vol. 21, pp. 1-11, 2013.

[46] A. M. F. Kamel, "Role of faculty development program in improving teaching and learning," Saudi Journal of Oral Sciences, vol. 3, no. 2, pp. 61-68, 2016.

[47] J. S. Kawalekar, "The values of life skills in higher education," IOSR Journal of Research and Method in Education, vol. 7, no. 3, pp. 43-46, 2017.

[48] R. I. Rahayu, A. Y. Huda, K. H. Sonhadji, and S. Utaya, "Life skills curriculum development at university," International Journal of Civil Engineering and Technology, vol. 10, no. 2, pp. 558-573, 2019.

[49] Y. Mehralizadeh, "New reforms in the management of university transition from central to decentralized (universitybased management) in Iran," UK Higher Education Policy, vol. 18 , no. 1 , pp. $67-82,2005$ 